\title{
クラッド歯車成形についての基礎的研究*
}

\author{
加 藤 浩 三*1, 近 藤一 義*2, 加 藤 貴 裕 $^{* 3}$
}

\section{Deformation Process of Clad Spur Gear}

Kohzoh KATOH, Kazuyoshi KONDO and Takahiro KATOH

\begin{abstract}
The purpose of this research is to develop a new plastic deformation process to fabricate a clad spur gear made of steel for inner and stainless steel for outer. The feasibility of the new plastic deformation process was confirmed through an experimental simulation with alternative material; aluminum. The new process is composed of deep drawing, ironing, and final die forging in which both gear profile formation and joining of two parts are simultaneously accomplished. As a result of the experiment the formed gear had enough filling in the die cavity and the force level during the die forging was lower in the case of the new clad type than in the case of the single material type. The formability was discussed from the view point of the metal flow in the radial direction during the die forging.
\end{abstract}

Key Words : Plastic Forming, Forging, Deep Drawing, Formability, Gear, Clad

\section{1. 緒言}

近年, 積層複合材料の適用技術が発達してきており， 压延によるクラッド板材の成形(1)，およびこれを用い たプレス成形が研究され(2) (6)，あるいは実用化されて きている，これらの積層複合材料は，異種材料を積層 することにより，単体の材料では得られない新たな機 能を得ること，あるいは高価な原材料の利用割合の低 減により製造コストを削減することを目的としてい る.このような積層複合材料の適用例としては，耐錆 を目的とした海水淡水化装置，滅菌層に浸される医療 機器，あるいは化学プラントなどがある。これらの製 品の一部はクラッド压延板材を用いたプレス成形によ り製造することが可能である。けれども，歯車やスプ ラインなど, 元来, 板素材ではなくバルク素材を利用 する機械要素のプレス成形では，これらのクラッド压 延材を適用することができないため，積層複合材料製 品の適用例は見られない.

* 原稿受付 1997 年 11 月 19 日.

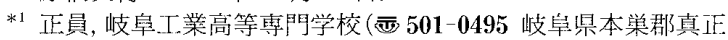
町).

*2 正員, 名吉屋大学工学部(画4648603 名古屋市千種义不老 团).

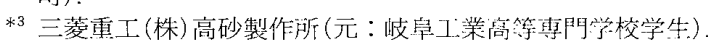

本研究では以上を踏まえて，外殼には板素材を用い 内層にはバルク材を用いて，これらを接合する新たな タイプの歯車(以下，クラッド歯車)の成形方法につい ての基礎的な検討を実施した。本研究の開発目標製品 はステンレスを外款とし炭素鋼を内層材としたクラッ ド歯車であるが，検討に際しては，基本的な塑性成形 特性を検証するため, 外款材, 内層材ともに工業用純 アルミニウムを用いた実験的シミュレーションを実施 した.

\section{2. クラッド歯車成形方法}

図 1 は提案するクラッド歯車成形方法の概要を示し たものである.まず，外殼用の板素材に深絞り加工と しごき加工を施して波形状を有するカップを成形す る。次にこのカップの取部と底部をトリミングし円筒 波形状プリフォーム(中間素材)を成形する。最後にこ の円筒波形状プリフォームの内部に厚肉の中空内層材 を挿入して冷間型鍛造を行う。この最後の工程では, 外殼部に歯車形状を成形すると同時に両素材の接合を 実現する。

\section{3. 実 験 方 法}

$3 \cdot 1$ 深絞りによる波形状プリフォームの成形 


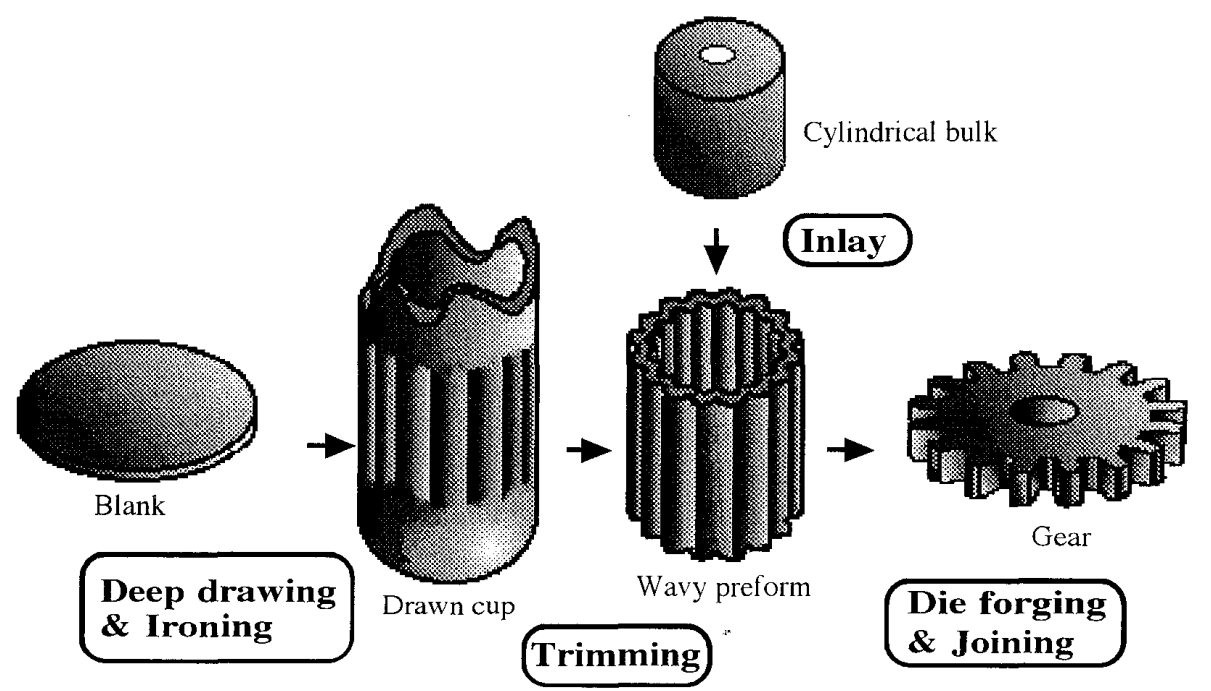

Fig. 1 Schematic view of new process for clad gear deformation

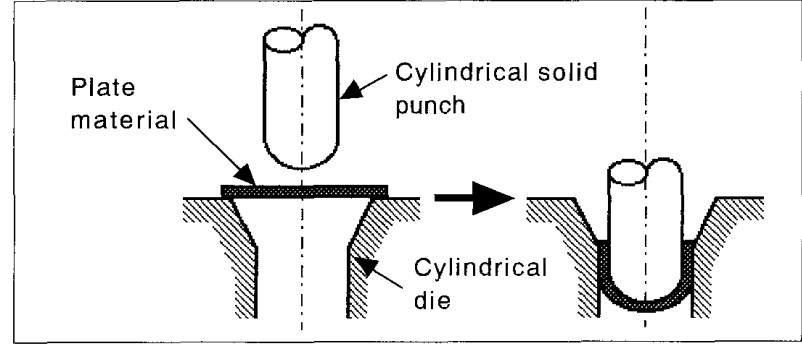

(a) First deep drawing

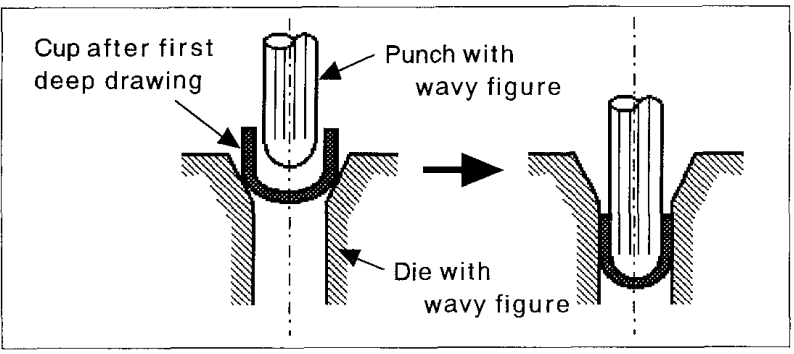

(b) Redrawing

Fig. 2 Schematic view of deformation of wavy preform

図 2 に波形状プリフォームを成形するための深絞り 工程の概要を示した。この工程は二つの深絞り工程に より構成される。まず，ストレート形状のパンチを用 いた第 1 絞り工程 $(\mathrm{a})$ により,板素材をカップ形状にす る。次に波形状を有するパンチとダイを用いた再絞り 工程 (b)により，波形状を有するカップを成形する. 表 1 に深絞り工程の加工条件を示した。第 1 絞り工程 には㨁径 $19.0 \mathrm{~mm}$ のストレートパンチと孔径 25.0 $\mathrm{mm}$ のダイを用いた。再絞りには基準円直径 16.78 $\mathrm{mm}$ の波形状を有するパンチと基準円直径 $18.78 \mathrm{~mm}$ の波形状を有するダイを用いてクリアランスを 1.0 $\mathrm{mm}$ とした。これにより,プリフォームの肉厚は 1.0
Table 1 Experimental conditions of deep drawing for wavy preform deformation

\begin{tabular}{|c|c|c|c|c|}
\hline & & Material & Feature & Size \\
\hline \multirow[b]{2}{*}{ Punch } & $\begin{array}{l}\text { First } \\
\text { deep } \\
\text { drawing }\end{array}$ & SKDII & Misumi corp. & $\phi 19.0 \times 85 \operatorname{mn} \quad r_{p}: 9.0$ \\
\hline & Redrawing & SKDH 1 & Misumi corp. & $\begin{array}{l}\text { Base circle diameter } \phi 16.78 \mathrm{~mm} \\
\text { Sine curve Amplitude } 0.08 \mathrm{~mm} \\
\text { Height } 100 \mathrm{~mm} \\
\text { Number of waves } 16 \\
r_{p}: 6.0\end{array}$ \\
\hline \multirow[b]{2}{*}{ Die } & $\begin{array}{l}\text { First } \\
\text { deep } \\
\text { drawing }\end{array}$ & SKDI 1 & Misumi corp. & $\begin{array}{l}\text { Height } 40 \mathrm{~mm} \\
\text { Outer diameter } \phi 45 \mathrm{~mm} \\
\text { Inner diameter } \phi 25 \mathrm{~nm} \\
\mathrm{rd}: 5 \mathrm{~mm} \quad \alpha ; 20=\end{array}$ \\
\hline & Redrawing & SKDII & $\begin{array}{l}\text { Quenching } 820^{\circ} \mathrm{C} \\
\text { (Water cooling) } \\
\text { Tempering } 150^{\circ} \mathrm{C} \\
\text { (Furnace cooling) }\end{array}$ & $\begin{array}{l}\text { Height } 40 \mathrm{ml} \\
\text { Outer diameter } \phi 45 \mathrm{~mm} \\
\text { Base circle diameter } \phi 18.78 \mathrm{~mm} \\
\text { Sine curve Amplitude } \\
0.08 \text { times of base circle radius } \\
\text { Number of waves } 16\end{array}$ \\
\hline & Blank & A 1050 & $\begin{array}{l}\text { Annealing } 420^{\circ} \mathrm{C} \\
\text { (Air cooling) }\end{array}$ & $\phi 43.0 \times 1.0 \mathrm{~mm}$ \\
\hline \multicolumn{2}{|c|}{ Lubricant } & $\begin{array}{l}\text { Beef } \\
\text { tallow }\end{array}$ & $\begin{array}{l}\text { First deep drawing } \\
\text { Redrawing }\end{array}$ & $\begin{array}{l}\rightarrow \text { Die side only } \\
\rightarrow \text { Die side only }\end{array}$ \\
\hline
\end{tabular}

$\mathrm{mm}$ になる，両工程とも潤滑剂に牛脂を用い，素材の 片面(ダイ側)のみに塗布した。

なお，最適なプリフォーム形状を選択することは， 本加工方法実現のための主要な構成要素である。けれ ども,この最適化は後の課題とし, 本検討では, 先見 的に定めたプリフォーム形状を用いている.

$3 \cdot 2$ 冷間型鍛造冷間鍛造に用いた実験装置の 概要を図 3 に示した。本装置の能力 $250 \mathrm{kN}$ の油圧プ レスに設置して加工を実施した.ここでは便宜的に下 部のパンチは固定し, 上部のパンチのみで加工を行う 片打ち機構を用いた。上下 2 個のパンチ(2)の間にプリ フォーム(7)と内層材とを挿入し, 上部のパンチを圧下 


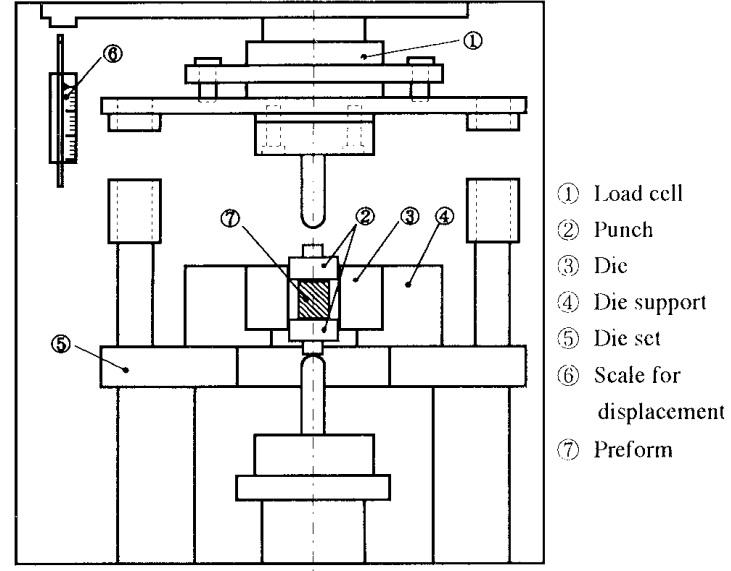

Fig. 3 Experimental apparatus for die forging

することにより，両材料をダイ(3)の型孔内に充填させ る。この際, 両素材の接合と外殼材の歯車成形とを同 時に実現する。本装置ではロードセル(1)により加工力 を測定し，変位計(6によりパンチストロークを測定す る。

冷間型鍛造の加工条件を表 2 に示した。製品となる 歯車の諸元を基準ピッチ円直径 $24 \mathrm{~mm}$, モジュール 1.5 , 歯数 16 枚とした。 パンチおよびダイの孔形状の 諸元は製品歯車の諸元と同じである。高さ $15 \mathrm{~mm} の$ 波形状プリフォームの内側に外径 $\phi 15.5 \mathrm{~mm}$, 内径 $\phi 7.5 \mathrm{~mm}$, 高さ $15 \mathrm{~mm}$ の中空円筒形のアルミニウム 素材を挿入し内層材として用いた。な押，内層材を中 空とした理由は，冷間鍛造時に材料の半径方向の分流 を促し, 加工力の低減と材料の型孔内の充填を図るた めである。潤滑剤には牛脂を用い, 波形状プリフォー ムの外周側に塗布した。

\section{4. 結果と考察}

$4 \cdot 1$ クラッド歯車成形 図 4 に示した写真は, クラッド歯車の成形例である，外款部に歯車形状が成 形されて扔り，提案する方法によりクラッド歯車の成 形が可能であることが確認された。両材料の界面は波 形状となっており，歯車使用時に負荷される円周方向 のせん断力に対して有利であることが期待される。ま た，図 5 はクラッド歯車の軸方向断面の写真である. 界面輪郭を明確にするためスケッチを併せて示した。 界面は軸に平行ではなく，厚み方向の中心部が半径方 向外側へ膨らんだ形状になっている．以上の図 4 と 5 の結果から，両材料の接合界面は三次元的に入り組ん だ形状となっていることが確認された。

一般に, 塑性加工にかかわる接合機構は，（1）金属 同士の直接接触に基づく金属接合(压接)と，(2)かし
Table 2 Experimental conditions for cold die forging

\begin{tabular}{|c|c|c|c|}
\hline & Material & Feature & Size \\
\hline Punch & SKDII & $\begin{array}{l}\text { Kohara gear } \\
\text { industry corp. } \\
\text { SSG1.5-16 }\end{array}$ & $\begin{array}{l}\text { Height } 30 \mathrm{~mm} \\
\text { Pitch circle diameter } \phi 24 \mathrm{~mm} \\
\text { Module } 1.5 \\
\text { Number of tceth } 16\end{array}$ \\
\hline Die & SKD1 1 & $\begin{array}{l}\text { Misumi corp. } \\
\text { FMSD45-40.0- } \\
\text { P12.50-S3-Cr13.0 }\end{array}$ & $\begin{array}{l}\text { Height } 40 \mathrm{~mm} \\
\text { Outer diameter } \phi 45 \mathrm{~mm} \\
\text { Pitch circle diameter } \phi 24 \mathrm{~mm} \\
\text { Module } 1.5 \\
\text { Number of teeth } 16\end{array}$ \\
\hline $\begin{array}{l}\text { Wavy } \\
\text { preform }\end{array}$ & $\mathrm{A} 1050$ & $\begin{array}{l}\text { Annealing } 420^{\circ} \mathrm{C} \\
\text { (Air cooling) }\end{array}$ & $\begin{array}{l}\text { Base circle diameter } \\
\text { (Outer) } \phi 18.78 \text { mito } \\
\text { (Inncr) } \phi 16.78 \mathrm{~mm} \\
\text { Sine curve Amplitude } \\
0.08 \text { times of base circle } \\
\text { Number of waves } 16 \\
\text { Height } 15 \mathrm{madius}\end{array}$ \\
\hline $\begin{array}{c}\text { Cylindric } \\
\text { bulk }\end{array}$ & A 1050 & $\begin{array}{l}\text { Annealing } 420^{\circ} \mathrm{C} \\
(\text { Air cooling })\end{array}$ & $\begin{array}{l}\text { Diameter } \\
\text { (Outer) } \phi 15.5 \mathrm{mma} \\
\text { (Inner) } \phi 7.5 \mathrm{mal} \\
\text { Height } 15 \mathrm{~mm}\end{array}$ \\
\hline $\begin{array}{l}\text { Product } \\
\text { (Gear) }\end{array}$ & 11050 & & $\begin{array}{l}\text { Pitch circle diameter } \phi 24 \text { mol } \\
\text { Module } 1.5 \\
\text { Number of teeth } 16\end{array}$ \\
\hline
\end{tabular}

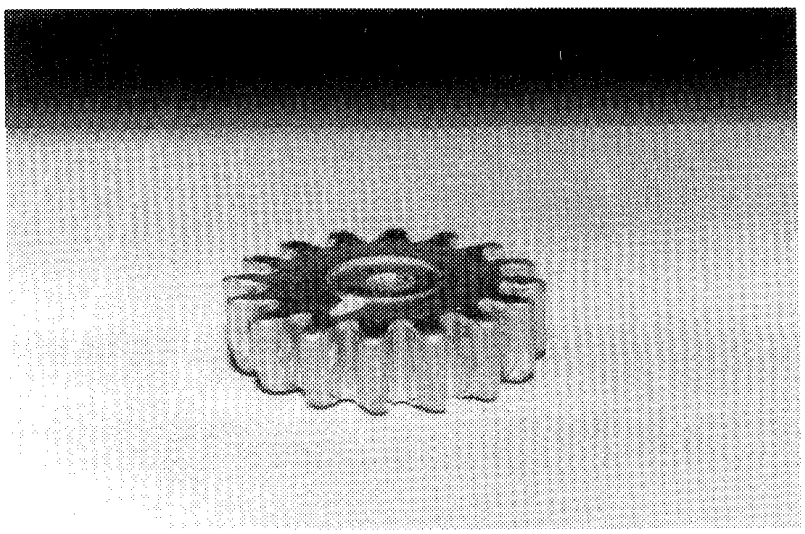

Fig. 4 Deformed clad gear. Joint face has wavy profile.

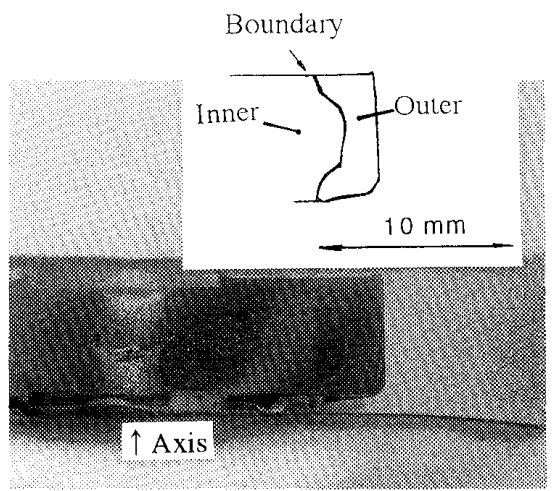

Fig. 5 Cross section of deformed clad gear cut in axial direction. Boundary has convex contour.

めに代表される構造締結とに大別される。本加工工程 における接命機構は，接合界面の形状が入り組んだも のであることから，後者の構造締結に類するものであ ると考える。したがって，異種金属材料の接合の場合 
において，実質的な金属接合が実現され難い場合であ っても締結一体部材としての接合強度を維持しうるこ とが期待される。この利点は，外耪材として波形状フ リフォームを用いたことに基づいている。図6には， 深絞り加工後の波形状プリフォーム, 冷間鍛造前のプ リフォーム抢よび, 冷間鍛造後の歯車の外観写真を併 せて示した。

$4 \cdot 2$ 加工力の検討 提案する加工法では，最終 の冷間鍛造工程において接合が行われ、これにより， クラッド㐘車の成形が実現される。この工程における 加工力のレベルを, 従来の単一素材による歯車鍛造の 加工力と比較することは，金型工具寿命の観点扢よび プレス能力の観点から重要である，比較に用いた単一 素材の高さ抢よび内径は, クラッド材用の波形状プリ フォームと同一の $15 \mathrm{~mm}$ 抢よび $\phi 7.5 \mathrm{~mm}$ とした。 ま た，体積をクラッド材の全体積と同一にするため外径 を $\phi 17.5 \mathrm{~mm}$ とした。単一素材から成形したテストピ ースの外観写真を図 7 に示した。両条件の加工力を比 較するため, 加工力とストロークの関係を図 8 に示し

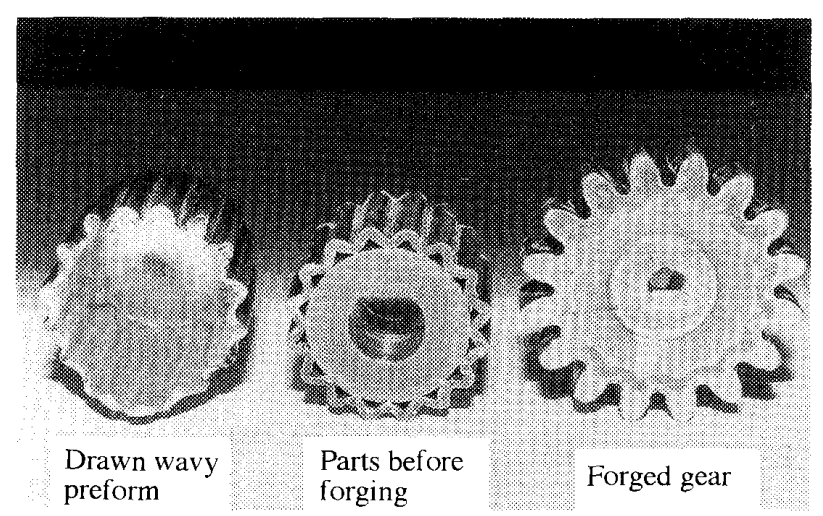

Fig. 6 Drawn wavy preform, parts before forging, and forged gear.

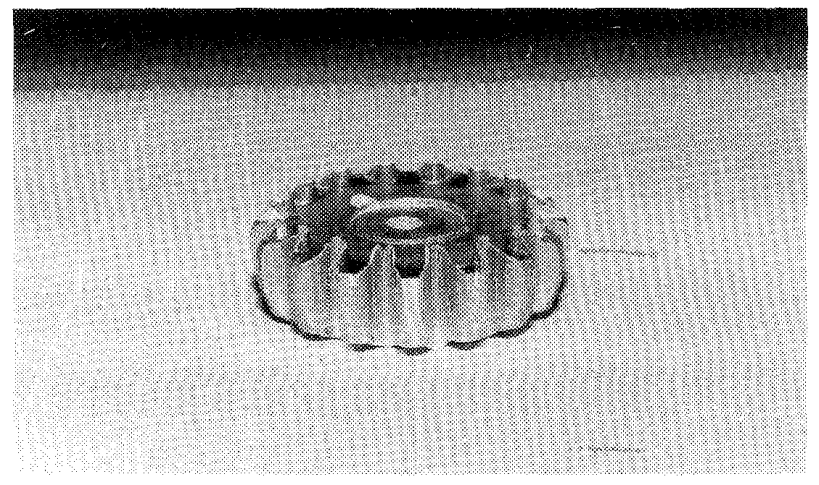

Fig. 7 Deformed gear from single material. Filling of teeth is not sufficient. Center hole diameter is smaller.
た、クラッド歯車の場合の最大加工力は $130 \mathrm{kN}$ であ り，単一素材から加工した場合の最大加工力 $150 \mathrm{kN}$ と比較すると，約 $20 \mathrm{kN}$ 低い．今回の実験では，ロー ドセルの能力の制約のため単一素材の加工を $150 \mathrm{kN}$ で終了したが,クラッド歯車の場合と同程度の材料充 填を得るためには，より大きい加工力が必要である。 この場合にはクラッド歯車における加工力の低減代は $20 \mathrm{kN}$ よりさらに大きいものと考えられる。

次に，加工力の差異の理由を明らかにするため材料 の型孔内への充填について考察する. 図 4 の外観写真 より明らかなようにクラッド歯車では, 単一素材から 成形したものと比較して, 歯先までの材料充填が著し い. 一方, 図 7 の単一素材から成形した場合は歯先に 十分に材料が充填して扔らず，特に，図 7 中の下端面 側では末充填が顕著である。また，半径方向の内向き の材料流動による内孔の直径減少が著しく，充填した 㐘末の部分 (円筒の上端面部)からはバリが生じてい る.内孔直径についてのクラッド歯車との差異の理由 は，単一素材の場合は半径方向外向きの材料流動の抵 抗が大きく，内向き流動が顕著になったためである. クラッド歯車の場合には，外向きの材料流動に対する 抵抗が少ないために，材料の歯形孔内への充填が顕著 であり，また内孔直径の減少もわずかであると考え る.

一般に型鍛造の行程終期において材料が型孔内に充 填され密閉状態に近づくと，材料の逃げ場がなくなり 加工力が急増する。したがって，これを回避するため には, 材料表面のうち, 工具との接触の無い表面(以降 「自由表面」と称す)学行程終期までできる限り維持す ることが有効である(7).

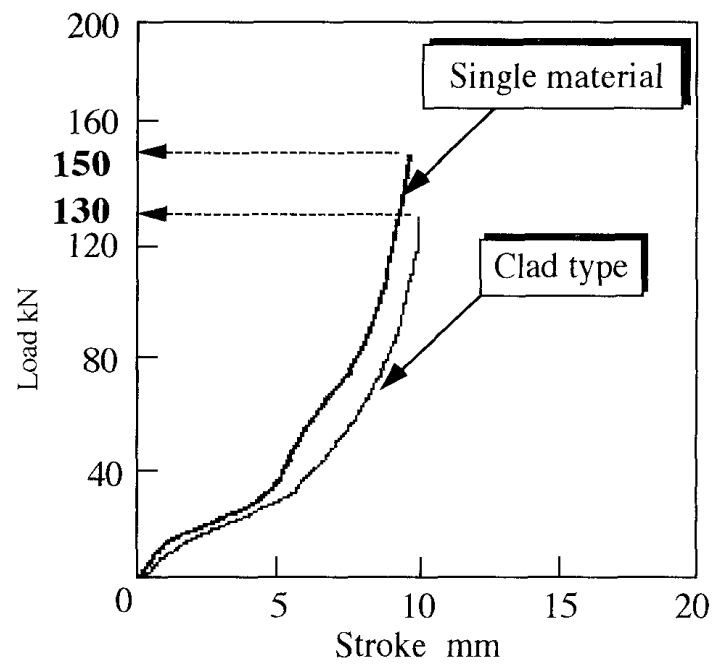

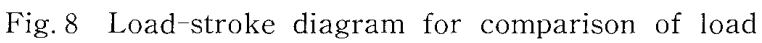
level 
図 9 はクラッド歯車の場合に外向きの材料流動に対 する抵抗が少ない理由を, 自由表面積の観点から考察 するための写真であり，冷間鍛造の加工行程に伴う内 外両部材の接触状況を示している。例えば，左から二 つめの加工途中（ストローク $8.0 \mathrm{~mm}$ )のテストピース を見ると, 内層材と外殼材の間には自由表面としての 隙間が残っている.この隙間は以降の行程の進行に伴 い次第に減少するが, 元来, これらの隙間が全くない 単一素材の場合と比較すると, 自由表面の観点から, 内層材の半径方向外向きの材料流動が容易であると推 察される.

\section{5. 結言}

本研究ではクラッド歯車成形の開発を目的として, アルミニウム材料を用いたシミュレーション成形実験 を試みた。その結果，以下の点が明らかになった。

（1）波形状プリフォームに円筒形状の内層材を挿 入して，接合と歯車形状成形とを同時に実現する冷間 形鍛造するタイプの新たな加工工程により,クラッド 歯車を成形することができた。

（2）新たなクラッド歯車成形の冷間鍛造工程につ いて, 加工力レベルを検証するため, 単一素材の型鍛 造との比較を行った。 その結果, 新たな加工法では加 工力が低減された。本実験の範国では, この低減代は 約 $20 \mathrm{kN}$ であった。 また，材料の自由表面と塑性流

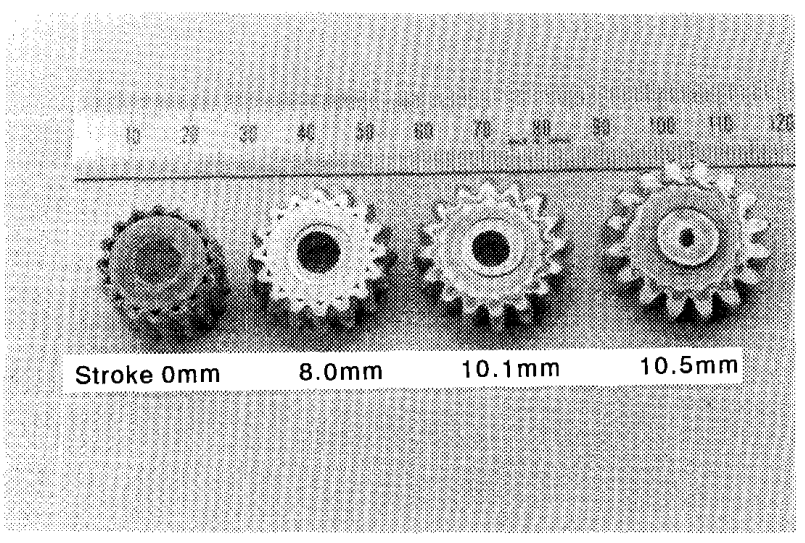

Fig. 9 Transition of contact free area of material.

動の観点から新加工法における加工力低減の理由が考 察され，波形状プリフォームは行程中の自由表面の維 持に有利であり，これが加工力低減に寄与しているも のと推定された。

\section{文献}

（1）川样高雄，塑性と加工，32-360(1991)，3-12.

(2) 平岩正至・近滕一義, 機論, 40-336 (1974), 2398-2406.

(3) 平岩正至・近藤一義, 機論, 42-360 (1976)，2625-2631.

(4) 平岩正至 - 近藤一義, 機論, 49-440, C (1983), 695-703.

（5）平岩正至・近藤一義, 機論, 50-455, C (1984), 1298-1305.

（6）近藤一義・平岩正至, 塑性と加工, 32-360(1991), 13-19.

（7）近滕一義, 塑性と加工; 24-271 (1983), 801-808. 